\title{
Expression level of integrin $\alpha 5$ on tumour cells affects the rate of metastasis to the kidney
}

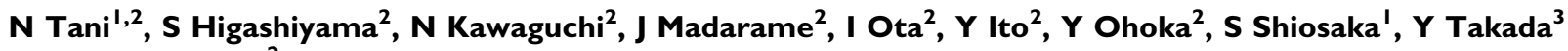 \\ and $\mathbf{N}$ Matsuura*,2
}

'Division of Structural Cell Biology, Nara Institute of Science and Technology (NAIST), 89 I 6-5 Takayama, Ikoma, Nara 630-0 I 0 I, Japan; ${ }^{2}$ Department of Pathology, School of Allied Health Science, Faculty of Medicine, Osaka University, I-7 Yamada-oka, Suita, Osaka 565-08I 7, Japan; ${ }^{3}$ Department of Vascular Biology, The Scripps Research Institute, 10550 North Torrey Pines Road, La Jolla, CA 92037, USA

\begin{abstract}
Tumour metastasis is known clinically to have organ specificity. We hypothesised that integrins might be involved in determining the organ specificity of tumour metastasis. Here, we report the results of spontaneous metastasis tested in nude mice that were inoculated with Chinese hamster ovary $(\mathrm{CHO})$ cells expressing integrin $\alpha 5 \beta \mid$ at various levels. The growth of the primary tumour inversely correlated with the $\alpha 5$ expression level on $\mathrm{CHO}$ cells, which is consistent with a previous report (Schreiner et al, I99l). The rates of pulmonary, lymph node, and adrenal metastases that developed in nude mice were not related to changes of the $\alpha 5$ expression level on $\mathrm{CHO}$ cells. Kidney metastasis developed in $40 \%$ of nude mice inoculated with $\alpha 5 \mathrm{~B} 2$ cells ( $\mathrm{CHO}$ cells overexpressing $\alpha 5$ ) and in $20 \%$ of mice with $\mathrm{CHO}-\mathrm{KI}$ cells ( $\mathrm{CHO}$ cells expressing native $\alpha 5$ ), whereas inoculation with $\mathrm{CHO}-\mathrm{B} 2$ cells ( $\alpha 5$-defective mutants) and $\alpha 5 \mathrm{CHO}$ cells with the highest expression of $\alpha 5$ did not lead to development of kidney metastasis. Furthermore, $\alpha 5 \mathrm{CHO}$, which shows the slowest growth of these cell types, did not lead to primary tumours in nude mice. These findings suggest that there is an appropriate level of $\alpha 5$ expression on tumour cells that leads to metastasis. Microscopic observations revealed that micrometastasis in the kidney was formed in glomeruli. An adhesion assay using frozen sections of the kidney demonstrated that $\alpha 5 \mathrm{~B} 2$ cells, but not $\mathrm{CHO}-\mathrm{B} 2$ cells, effectively adhered to glomeruli. Kidney metastasis in vivo and the adhesion of 5 B 2 to glomeruli shown ex vivo were significantly suppressed by the administration of GRGDS peptide. Finally, we conclude that the interaction of $\alpha 5 \beta \mid$ on tumour cells with fibronectin in kidney glomeruli is involved in kidney metastasis and that the tumour has appropriate levels of integrins crucial for metastasis.

British Journal of Cancer (2003) 88, 327-333. doi:I0.1038/sj.bjc.66007I0 www.bjcancer.com
\end{abstract}

(c) 2003 Cancer Research UK

Keywords: tumour metastasis; $\alpha 5 \beta$ I integrin; kidney; $\mathrm{CHO}-\mathrm{KI}$

\section{INTRODUCTION}

Clinically, it is well known that tumour metastasis has organ specificity. Selectivity of the organs to which the tumour metastasises is thought to be affected by interactions between the tumour and molecules surrounding it (seed and soil theory) (Paget, 1898), and the direction of blood flow (mechanical theory) (Ewing, 1928). The process of tumour metastasis consists of detachment of cells from the primary tumour, invasion of extracellular matrix (ECM), intra- and extravasation, and growth at the secondary site. Numerous data have been reported to support the seed and soil theory as well as the mechanical theory by means of these processes. In B16-F10 melanoma cells and reticulum-cell sarcoma cells, organ specificity in their binding in vitro and ex vivo reflected the organ specificity of their metastatic distribution in vivo (Nicolson and Winkelhake, 1975; Netland and Zetter, 1984). Tumour cells that metastasised selectively to a specific organ showed intense adhesion to the endothelial cells derived from this organ (Nicolson, 1988; Pauli and Lee, 1988). Furthermore, an adhesion molecule designated Lu-ECAM-1 is

\footnotetext{
*Correspondence: Dr N Matsuura;

E-mail: matsuura@sahs.med.osaka-u.ac.jp

Received 17 April 2002; revised 10 October 2002; accepted 18 October 2002
}

specifically expressed on endothelial cells derived from the lung but not from other organs (Zhu et al, 1991). These findings suggest that there might be specific molecules or proportions of proteins in endothelial cells or ECM proteins in organs, that determine the metastatic sites of tumour cells. Therefore, adhesion molecules appear to be crucial for mediating the tumour-endothelial or tumour-ECM interactions.

Integrins are transmembrane glycoproteins that consist of $\alpha$ and $\beta$ subunits and mediate cell-matrix and cell-cell adhesions (Hynes, 1992). Varieties of $\alpha$ and $\beta$ subunits produce ligand selectivity to ECM (Albelda and Buck, 1990). To elucidate the role of integrins in tumour progression leading to metastasis, integrin expression levels have been compared in normal and tumour cells, or in primary and secondary sites in cancer patients using polymerase chain reaction (PCR), in situ hybridization, or immunohistochemical techniques.

Changes of integrin expression or its localisation in transformed cells appear to contribute either positively or negatively to the transformed cell phenotype. For instance, $\alpha 5 \beta 1$ integrin is a key molecule in the invasion at least of melanoma, osteosarcoma, and glioblastoma cells, while $\alpha \mathrm{V} \beta 3$ integrin also appears to be associated with increased invasiveness (Ruoslahti, 1992). The localisation of the fibronectin receptor on the cell surface is altered in the malignant transformation of cultured human cells in comparison with normal cells (Akiyama et al, 1990). In sarcoma 
virus transformation of several rodent cell lines, $\alpha 5 \beta 1$ integrin disappears from the cell surface, whereas $\alpha 3 \beta 1$ levels remain constant (Heino, 1993). In melanoma, alterations of $\alpha 2 \beta 1, \alpha 3 \beta 1$, and $\alpha 6 \beta 1$ integrins appear to be associated with malignancy (Chen et al, 1991; Natali et al, 1991,1993; Moretti et al, 1993). In breast cancer, $\alpha 2 \beta 1, \alpha 5 \beta 1$, or $\alpha 6 \beta 4$ integrins seem to be crucial for malignant transformation (Pignatelli et al, 1991; Natali et al, 1992; Zutter et al, 1993; Weaver et al, 1997). In pancreatic carcinoma cell lines, expression of $\alpha 2, \alpha 3, \alpha 6, \beta 1, \beta 4$, and $\beta 5$ integrins was detected in adenocarcinomas and ampullary tumours, in the normal pancreas, reduced levels of expression occur, or in the case of some integrins there is no expression (Hall et al, 1991). These strategies are beneficial in that integrin expression is directly detected on tissues from patients or tumour cell lines.

In another strategy, tumour cells or mice with genetic changes of integrin expression have been used for analysing the effects of integrin on tumourigenesis and organ-preferential metastasis. Rhabdomyosarcoma (RD) cells transfected with cDNA encoding the $\alpha 2$ subunit enhanced metastasis in nude mice, demonstrating the specific effect of $\alpha 2 \beta 1$ integrin on metastasis (Chan et al, 1991). CHO cells transfected with $\alpha 4$ cDNA caused experimental bone metastasis in nude mice, suggesting that bone metastasis was induced by interactions between $\alpha 4 \beta 1$ on tumour cells and VCAM1 on stromal cells in the bone marrow (Matsuura et al, 1996). Here, we constructed $\mathrm{CHO}$ transfectants expressing $\alpha 5 \beta 1$ at various levels and examined metastatic sites in nude mice. In this study, we especially focused on the relation between the change in $\alpha 5 \beta 1$ levels on tumour cells and rates of metastasis.

\section{MATERIALS AND METHODS}

\section{Cells and culture conditions}

CHO-K1 cells (ATCC, VA, USA) were used as parent cells in this study. CHO-B2 cells are $\alpha 5$-defective mutants of $\mathrm{CHO}-\mathrm{K} 1$ cells, that exclusively express $\alpha 5 \beta 1$ integrin (Schreiner et al, 1989), and their transfectants were designated as $\alpha 5 \mathrm{~B} 2$ and $\alpha 5 \mathrm{CHO}$ cells, respectively. A pBJ-1 vector carrying $\alpha 5 \mathrm{cDNA}$ driven by the $\mathrm{SR} \alpha$ promoter (Takebe et al, 1988) was transfected into CHO-K1 or CHO-B2 cells. Cells expressing $\alpha 5$ were selected by flow cytometric sorting and by resistance to geneticin (G418). $\alpha 5 \mathrm{~B} 2 \mathrm{~F} 187 \mathrm{~A}$ cells are transfectants of CHO-B2 cells with mutant $\alpha 5 \mathrm{cDNA}$ containing an alanine substitution of phenylalanine 187 (Irie et al, 1995). Cells were maintained in Dulbecco's modified Eagle's medium (DMEM, Nihonseiyaku, Tokyo, Japan), supplemented with $10 \%$ fetal bovine serum (FBS, Dainippon Pharmaceutical Co., Ltd, Tokyo, Japan) and $50 \mathrm{U} \mathrm{ml}^{-1}$ of penicillin plus $50 \mu \mathrm{g} \mathrm{ml}^{-1}$ of streptomycin (Life Technologies, Frederick, ML, USA) in $10 \% \mathrm{CO}_{2}$.

\section{Flow cytometric analysis}

Cells in DMEM supplemented with $1 \%$ FBS and $0.03 \%$ sodium azide were incubated with a monoclonal antibody against human/ hamster $\alpha 5$ (KH72) for $30 \mathrm{~min}$ at $4{ }^{\circ} \mathrm{C}$. After washing with DMEM as described above, the cells were incubated with FITC-conjugated mouse IgG (DAKO, Copenhagen, Denmark) for $30 \mathrm{~min}$ at $4^{\circ} \mathrm{C}$. After washing, cells were resuspended with the same DMEM and analysed by FACS Calibur (BD Biosciences, CA, USA).

\section{Spontaneous metastasis model in nude mice}

Nude mice (BALB/cAnNCrj-nu/nu, 4 weeks, female) were subcutaneously injected with $1 \times 10^{6}$ cells of parental, mutant, or transfectant $\mathrm{CHO}$ cells. Subcutaneous tumours were measured with a dial-caliper twice a week and volumes were determined using the formula width ${ }^{2} \times$ length $\times 0.52$. Each volume value indicates the mean \pm standard errors (s.e.). Primary tumours were removed surgically at a size of $2500-3500 \mathrm{~mm}^{3}$ to prevent mice from dying. The mice were killed and metastatic sites were examined 7-8 weeks after inoculation. To investigate whether kidney metastasis was caused by adhesion of $\alpha 5 \beta 1$ on tumour cells to fibronectin, the effects of intravenous tail vein injection of GRGDS or GRGES peptide ( $20 \mathrm{mg} \mathrm{kg}^{-1}$ in $50 \mu \mathrm{l}$ each) in PBS had been tested every other day starting from day 5 for 7 weeks.

\section{Histological analysis}

Kidney and lung were excised and fixed with formalin. Horizontal sections ( $6 \mu \mathrm{m}$ thick) were prepared from the centre of the tumour in paraffin-embedded tissue. The sections were stained with haematoxylin-eosin and metastatic sites were examined by microscopy.

\section{Adhesion assay}

A total of 96-well plastic plates were coated with $10 \mu \mathrm{g} \mathrm{ml}^{-1}$ of fibronectin in phosphate-buffered saline (PBS) for $2 \mathrm{~h}$ at $37^{\circ} \mathrm{C}$ and then treated with $3 \%$ bovine serum albumin (BSA) for $1 \mathrm{~h}$ at $37^{\circ} \mathrm{C}$, or were coated with only BSA for negative control. The cells $\left(5 \times 10^{4}\right.$ cells well $\left.^{-1}\right)$ in serum-free DMEM containing $0.1 \%$ BSA were added and incubated for $1 \mathrm{~h}$ at $37^{\circ} \mathrm{C}$. After removal of the medium, a $0.04 \%$ crystal violet solution was added and incubation was conducted for $10 \mathrm{~min}$ at room temperature. The wells were washed three times with PBS and $20 \mu \mathrm{l}$ of Triton X-100 was added for permeabilisation. After addition of distilled water to $100 \mu \mathrm{l}$, the optical density was measured at $550 \mathrm{~nm}$. The value indicates the mean \pm s.e. for triplicate data representing three independent experiments.

\section{Spreading assay}

Cells $\left(5 \times 10^{3}\right.$ cells well $\left.^{-1}\right)$ in serum-free DMEM containing $0.1 \%$ BSA were added to plates coated with $10 \mu \mathrm{g} \mathrm{ml}^{-1}$ of fibronectin (96 wells), and incubated for $3 \mathrm{~h}$ at $37^{\circ} \mathrm{C}$. The cells were photographed on slide film under microscopy and the images on the film were analysed by NIH Image (National Institutes of Health, Bethesda, MD, USA). The spreading area of each cell type was calculated. The value indicates the mean \pm s.e. for 20 cells randomly sampled.

\section{Migration assay}

Cell migration to soluble fibronectin was assessed by multiwell Boyden chambers (Neuro Probe, Gaithersburg, MD, USA). Polycarbonate filters (pore size of $8 \mu \mathrm{m}$ ) were coated with $10 \mu \mathrm{g} \mathrm{ml}^{-1}$ of fibronectin (Asahi Techno Glass, Tokyo, Japan) for $30 \mathrm{~min}$ at room temperature and air-dried. The lower part of the chamber was filled with $10 \mu \mathrm{g} \mathrm{ml}^{-1}$ of fibronectin in serum-free DMEM containing $0.1 \%$ BSA or with a medium containing BSA only. Cells $\left(2 \times 10^{4}\right.$ well $\left.^{-1}\right)$ in $50 \mu$ l of DMEM containing $0.1 \%$ BSA were applied to the upper part of the chamber and incubated for $3 \mathrm{~h}$ under $5 \% \mathrm{CO}_{2}$ at $37^{\circ} \mathrm{C}$. The upper side of the filter was scraped with a cotton swab. The filters were fixed with formalin and stained with haematoxylin. The number of cells on the lower side was counted. The value indicates the mean \pm s.e. for triplicate data representing three independent experiments.

\section{Adhesion assay on the tissue}

An adhesion assay on kidney sections was performed according to the Stamper-Woodruff assay (Stamper and Woodruff, 1976). The kidneys were removed from nude mice and immediately frozen by liquid $\mathrm{N}_{2}$. Horizontal sections $(10 \mu \mathrm{m}$ thick) used for one assay were prepared from the same tissues and mounted on glass slides. Mock-transfected CHO-B2 and $\alpha 5 \mathrm{~B} 2$ cells $\left(1 \times 10^{6}\right.$ cells in $1 \mathrm{ml}$ of DMEM supplemented with $10 \%$ FBS) were fluorescence-labelled by $3 \mu \mathrm{l}$ of $1 \mathrm{~mm}$ BCECF-AM DMSO solution (Wako Pure Chemical 
Industries, Ltd, Hokkaido, Japan) and incubated for $30 \mathrm{~min}$ at room temperature. Excess BCECF was washed off with PBS and the cells were resuspended in $10 \mathrm{~mm}$ HEPES ( $\mathrm{pH} 7.4)$. Cells $\left(1 \times 10^{5}\right.$ in $0.1 \mathrm{ml}$ of HEPES) were preincubated with GRGDS or GRGES peptide $\left(200 \mu \mathrm{g} \mathrm{ml}^{-1}\right)$ for $30 \mathrm{~min}$ at $4{ }^{\circ} \mathrm{C}$ and applied onto tissue sections marked by a wax pen and incubated for $30 \mathrm{~min}$ at room temperature with moderate rotation (60 r.p.m.). Unbound cells were washed away with PBS and the sections were fixed with $3 \%$ glutaraldehyde in PBS. Cell nuclei were stained with propidium iodide. The sections were air-dried and the number of cells adhering to glomeruli were counted by confocal laser microscopy (LSM-GB200, OLYMPUS, Tokyo, Japan). The value indicates the mean \pm s.e. for 20 glomeruli randomly selected and representing three independent experiments.

\section{Statistical analysis}

The $\chi^{2}$ test was used to determine the significance of the in vivo metastasis experiments. The statistical analysis of the adhesion assay was performed by Kruskal-Wallis ANOVA. A $P<0.05$ value was regarded as statistically significant.

\section{RESULTS}

\section{Expression level of $\alpha 5$ subunit on each $\mathrm{CHO}$ cell}

To confirm the expression level of the $\alpha 5$ subunit on each $\mathrm{CHO}$ cell type, we carried out a flow cytometric analysis (Figure 1). Since the counterpart of the $\alpha 5$ subunit is only the $\beta 1$ subunit, the expression level of the $\alpha 5$ subunit indicates that of $\alpha 5 \beta 1$ integrin. $\alpha 5 \mathrm{CHO}$ cells showed the highest level of $\alpha 5 \beta 1$ integrin. $\alpha 5 \mathrm{~B} 2$ cells had a higher expression of $\alpha 5 \beta 1$ than CHO-K1 (mock) cells with the endogenous level. No $\alpha 5$ expression was observed in CHO-B2 (mock) cells, which are $\alpha 5$-defective mutants. $\alpha 5$ expression on $\alpha 5 \mathrm{~B} 2 \mathrm{~F} 187 \mathrm{~A}$ cells was almost the same level as $\alpha 5 \mathrm{~B} 2$ cells.

\section{Growth of primary tumour in vivo and cell proliferation in vitro}

After the cells were inoculated subcutaneously into nude mice, the size of the tumour was measured twice a week (Figure 2). The growth of the primary tumour was inversely correlated with $\alpha 5$ expression levels on $\mathrm{CHO}$ cells as previously reported (Schreiner et al, 1991). $\alpha 5 \mathrm{CHO}$ cells expressing $\alpha 5 \beta 1$ at the highest level did not produce a primary tumour. In a cell-proliferation assay, $\mathrm{CHO}$ cells with increased $\alpha 5$ expression on fibronectin showed reduced cell proliferation as well as reduced cell growth in vivo (data not shown).

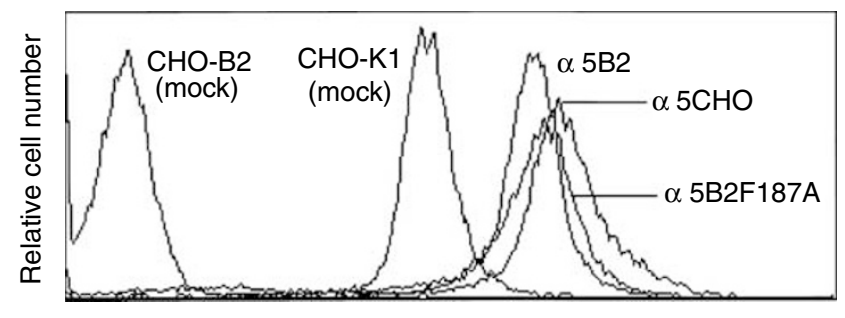

Relative fluorescence intensity

Figure I Flow cytometric analysis of $\alpha 5$ expression on $\mathrm{CHO}$. Human and Chinese hamster $\alpha 5$ was detected by $\mathrm{mAb} \mathrm{KH} 72$ on each $\mathrm{CHO}$ cell. $\mathrm{CHO}-\mathrm{KI}$ cells expressed $\alpha 5$ at the endogenous level and CHO-B2 cells, $\alpha 5$-defective mutant, did not express $\alpha 5$. Among three transfectants of $\alpha 5 \mathrm{~B} 2, \alpha 5 \mathrm{~B} 2 \mathrm{~F} / 87 \mathrm{~A}$, and $\alpha 5 \mathrm{CHO}$ cells, $\alpha 5 \mathrm{CHO}$ showed the highest expression of $\alpha 5$.

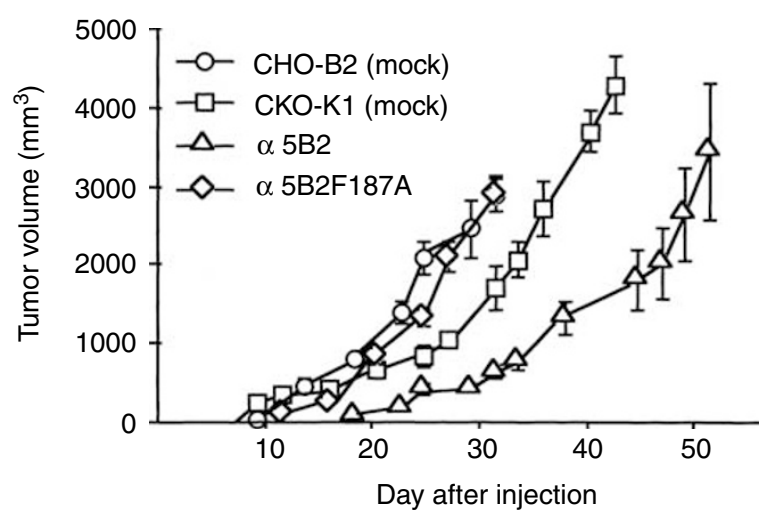

Figure 2 Growth of primary tumour in nude mice. Each growth curve shows primary tumour volume of nude mice inoculated subcutaneously with $\mathrm{CHO}$ cells $\left(10^{6}\right.$ cells mouse $\left.{ }^{-1}\right)$. The growth of tumour volume was reversely correlated with $\alpha 5$ expression level on $\mathrm{CHO}$ cells. In nude mice inoculated with $\alpha 5 \mathrm{CHO}$ cells, no primary tumour was observed. Each value shows the mean \pm s.e. $(n=8)$.

\section{Metastatic sites and rate of metastasis observed in nude mice subcutaneously inoculated with each CHO cell type}

To identify the role of $\alpha 5$ expression on CHO cells in metastasis, we examined the organs with spontaneous metastasis in nude mice (Table 1). Lung metastasis was frequently seen in nude mice inoculated with parent $\mathrm{CHO}-\mathrm{K} 1$ (mock, 100\%), $\alpha 5$-defective mutants (CHO-B2, mock, 90.4\%), or $\alpha 5$ transfectants $(\alpha 5 \mathrm{~B} 2$, 89.4\%). This means that lung metastasis at least in this study appears to be primarily because of physical trapping of $\mathrm{CHO}$ cells by microvessels rather than interactions between $\alpha 5 \beta 1$ on $\mathrm{CHO}$ cells and fibronectin. Metastases in adrenal glands and lymph nodes were observed in nude mice at a lower level of $0-30 \%$. These metastases also seem to have no relation to a change of $\alpha 5$ expressions on $\mathrm{CHO}$ cells. On the other hand, the rate of kidney metastasis changed in association with the expression levels of $\alpha 5$ on $\mathrm{CHO}$ cells. Both $\mathrm{CHO}-\mathrm{B} 2$ cells with no $\alpha 5$ expression and $\alpha 5 \mathrm{~B} 2 \mathrm{~F} 187 \mathrm{~A}$ cells expressing mutated $\alpha 5$ did not give rise to kidney metastasis in nude mice. CHO-K1 cells with a native level of $\alpha 5$ produced kidney metastasis in nude mice at levels of $22.7-27.7 \%$. $\alpha 5 \mathrm{~B} 2$ cells with a higher level of $\alpha 5$ than $\mathrm{CHO}-\mathrm{K} 1$ cells caused kidney metastasis at a higher level of $30-50 \%$. $\alpha 5 \mathrm{CHO}$ cells with the highest level of $\alpha 5$ did not give rise to kidney metastasis in nude mice, since $\alpha 5 \mathrm{CHO}$ cells could not produce a primary tumour because of their very slow growth. These findings indicate the possibility that kidney metastasis might be particularly caused by interactions between $\alpha 5 \beta 1$ on tumour cells and fibronectin in the kidney. Furthermore, kidney metastasis induced by $\alpha 5 \mathrm{~B} 2$ was significantly inhibited by intravenous administration of GRGDS peptide (10\%) when compared to GRGES peptide $(42.1 \%)$ $(P<0.05)$, whereas the administration of GRGDS peptide did not affect the metastatic rate of any other organs investigated. This suggests that the adhesion of $\alpha 5 \mathrm{~B} 2$ cells to fibronectin via integrin $\alpha 5 \beta 1$ might have a crucial role in the induction of kidney metastasis.

\section{Macroscopic and microscopic findings of kidney metastasis in nude mice}

The macroscopic appearance of kidney metastasis is shown in Figure 3A. The arrowhead indicates a metastatic site formed in the right kidney of a nude mouse inoculated with $\alpha 5 \mathrm{~B} 2$ cells, this mouse also has an adrenal metastasis. To identify where $\alpha 5 \mathrm{~B} 2$ cells were first trapped in the kidney, we observed micrometastatic sites in kidney sections stained with haematoxylin-eosin. In all nude 
Table I Metastasis formation of $\mathrm{CHO}$ and their transfectants inoculated subcutaneously into nude mice

\begin{tabular}{|c|c|c|c|c|c|}
\hline Cells and treatments & No. of mice analysed & \% Lung & \% Kidney & $\%$ Adrenal & \% Lymph node \\
\hline CHO-B2 (mock) & 21 & 90.4 & 0 & 19 & 9.5 \\
\hline $\mathrm{CHO}-\mathrm{KI}$ (mock) & 22 & 100 & $22.7 *$ & 27.2 & 13.6 \\
\hline$\alpha 5 B 2$ & 19 & 89.4 & $47.3 * * *$ & 21 & 10.5 \\
\hline$\alpha 5 \mathrm{CHO}$ & 10 & - & - & - & - \\
\hline$\alpha 5 \mathrm{~B} 2 \mathrm{~F} 187 \mathrm{~A}$ & 13 & 100 & 0 & 15.3 & 23 \\
\hline $\mathrm{CHO}-\mathrm{B} 2$ & 23 & 91.3 & 0 & 21.7 & 8.6 \\
\hline $\mathrm{CHO}-\mathrm{KI}$ & 18 & 88.8 & $27.7 *$ & 27.7 & 11.1 \\
\hline a5B2 clone I & 10 & 100 & $30 *$ & 20 & 10 \\
\hline$\alpha 5 \mathrm{~B} 2$ clone2 & 10 & 90 & $50 * *$ & 30 & 0 \\
\hline$\alpha 5 B 2+G R G D S$ & 20 & 90 & $10 *$ & 20 & 10 \\
\hline$\alpha 5 \mathrm{~B} 2+\mathrm{GRGES}$ & 19 & 100 & 42.1 & 21 & 10.5 \\
\hline
\end{tabular}

Mice were killed 7-8 weeks after inoculation. In metastasis inhibition experiment using GRGDS or GRGES peptide, $20 \mathrm{mg} \mathrm{kg}^{-}$ peptide was administered to mice every other day since 5 days after inoculatin. Since $\alpha 5 \mathrm{CHO}$ did not develop primary tumour, metastasis sites were not formed. The $\chi^{2}$ analysis shows that there is a significant difference compared with the metastasis rate CHO-B2 $(* P<0.05, * * P<0.01$, $* * * P<0.001)$. The values of $\alpha 5 B 2+G R G D S$ treatments were assessed by the $\chi^{2}$ analysis compared with that of $\alpha 5 B 2+G R G E S$ treatments.
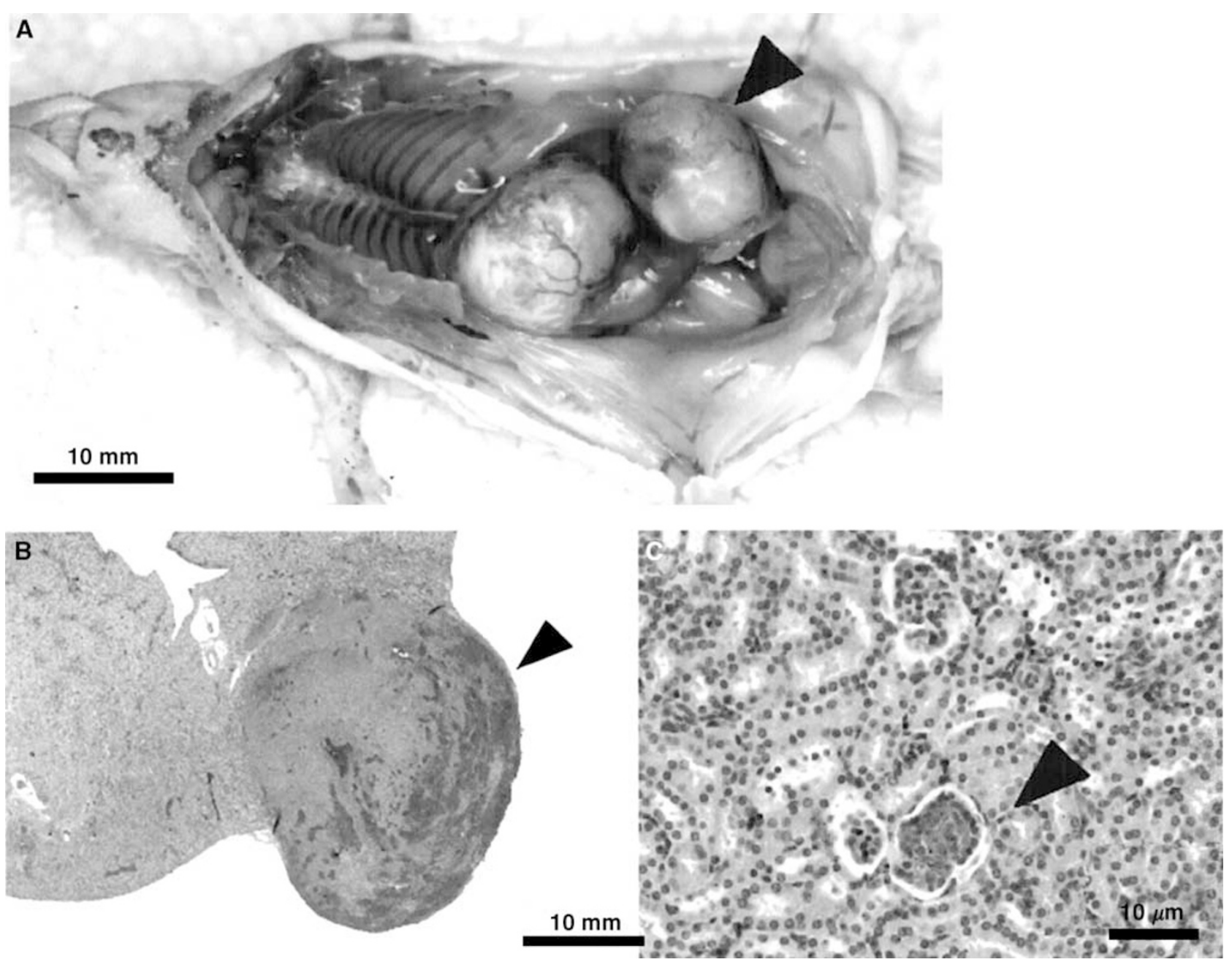

Figure 3 Macroscopic and microscopic findings of the kidney metastasis shown in a nude mouse inoculated with $\alpha 5 B 2$ cells. (A) a nude mouse with the kidney metastasis caused by $\alpha 5$ B2 inoculation. The mouse was in supine position and intraperitoneal examination was performed after the laparotomy. An arrowhead shows the metastasis site in the right kidney; this mouse also has the adrenal metastasis. (B) Haematoxylin and eosin(HE)-stained section of tumour (arrowhead) in the kidney. All kidney metastases were found in the kidney cortex region. (C) HE-stained section of micrometastasis (arrowhead) developed in the kidney glomerulus. The lower glomerulus formed a micrometastasis site caused by $\alpha 5$ B2 whereas the upper glomerulus was normal.

mice with kidney metastasis, metastatic sites were formed in the kidney cortex region (Figure 3B, arrowhead). Furthermore, all micrometastases were shown in the kidney glomeruli (Figure 3C, arrowhead). These findings demonstrate that kidney metastasis develops first by the adhesion of $\alpha 5 \beta 1$ on $\mathrm{CHO}$ cells to fibronectin in the kidney glomerulus. 


\section{Adhesion and migration of $\mathrm{CHO}$ cells to fibronectin in vitro}

To estimate whether it is cell adhesion or migration that is supposed to be crucial for kidney metastasis formation, the behaviour of each $\mathrm{CHO}$ cell type relative to fibronectin was analysed in vitro. In the adhesion assay, $\mathrm{CHO}$ cells with greater $\alpha 5$ expression effectively adhered to fibronectin, whereas $\alpha 5 \mathrm{~B} 2 \mathrm{~F} 187 \mathrm{~A}$ cells with the alanine mutation and CHO-B2 cells did not adhere to fibronectin (Figure 4A). Likewise, $\mathrm{CHO}$ cells showed an increase in

A

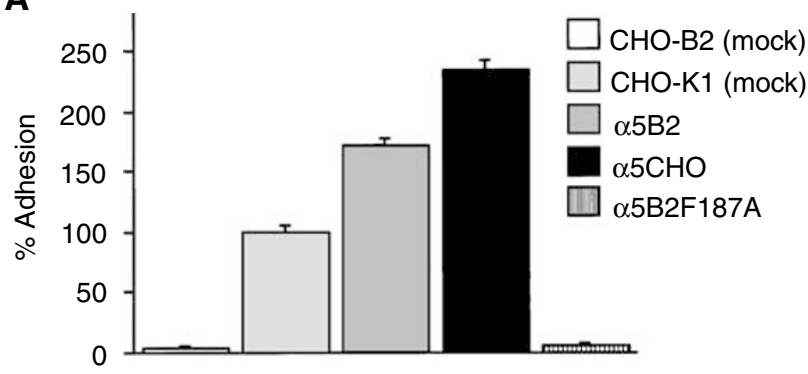

B

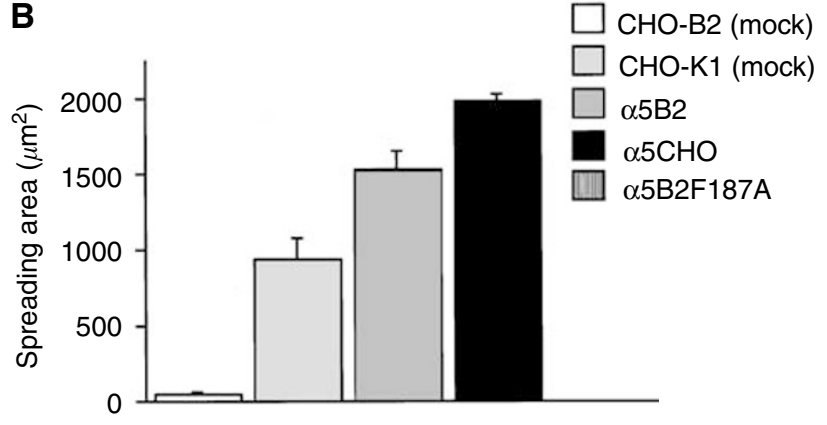

C

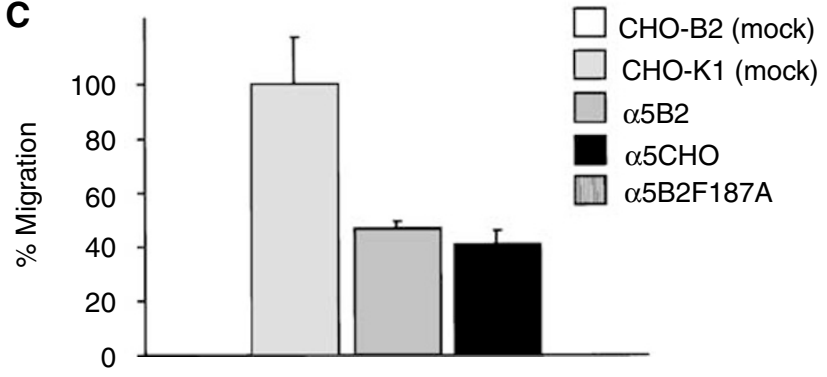

Figure 4 Adhesion and migration of $\mathrm{CHO}$ cells to fibronectin. (A) Adhesion assay demonstrating that adhesion activities to fibronectin in each $\mathrm{CHO}$ cell depend on $\alpha 5$ expression level. Cells $\left(5 \times 10^{4}\right.$ well $\left.^{-1}\right)$ in serumfree DMEM containing $0.1 \%$ BSA were plated on coated fibronectin $\left(\left.10 \mu \mathrm{g} \mathrm{ml}\right|^{-1}\right)$ and incubated for $1 \mathrm{~h}$ at $37^{\circ} \mathrm{C}$. Cells binding to fibronectin that were stained with crystal violet were assessed by measuring optical density at $550 \mathrm{~nm}$. Results are expressed as the percentage compared with $\mathrm{CHO}-\mathrm{KI}$ cells (mock). Each value is the mean \pm s.e. of triplicate data representative for three independent experiments. (B) Spreading assay quantifying increased binding area in cell adhesion to fibronectin compared with cell spreading on BSA. Each cell in serum-free DMEM containing $0.1 \%$ BSA was plated on coated fibronectin $\left(10 \mu \mathrm{g} \mathrm{ml}^{-1}\right)$ and incubated for $3 \mathrm{~h}$ at $37^{\circ} \mathrm{C}$. Each value is the mean \pm s.e. of 20 cells randomly selected. The same results were obtained in two independent experiments. (C) Boyden chamber assay evaluating migration acitivity of each $\mathrm{CHO}$ to soluble fibronectin. A chamber with $10^{5} \mathrm{cells}$ well ${ }^{-1}$ in the upper chamber and $10 \mu \mathrm{g} \mathrm{ml}^{-1}$ fibronectin in the lower chamber was incubated for $3 \mathrm{~h}$ at $37^{\circ} \mathrm{C}$ in $10 \% \mathrm{CO}_{2}$. The number of cells migrating to the lower side of the filter was assessed as a percentage compared with $\mathrm{CHO}$ $\mathrm{KI}$ cells (mock). Each value is the mean \pm s.e. of triplicate data, representative for three independent experiments.

cell spreading that correlated with the overexpression of $\alpha 5$ (Figure 4B). Since tumour cells in intravasation penetrate into blood vessels containing abundant soluble fibronectin $\left(300 \mu \mathrm{g} \mathrm{ml}^{-1}\right)$ in serum (Mosesson and Umfleet, 1970), the cell migration of each $\mathrm{CHO}$ cell type was estimated by a cell migration assay. In contrast to the results of adhesion and spreading assay, of all the $\mathrm{CHO}$ cells investigated, $\mathrm{CHO}-\mathrm{K} 1$ cells with the native level of $\alpha 5$ migrated most effectively to fibronectin (Figure 4C). These data are consistent with the theory that cell migration is controlled by dynamic interactions between cell receptors and substratum ligands in a manner representing events at the front and rear of the migrating cells (Palecek et al, 1996, 1997; Regen and Horwitz, 1992). The rate of kidney metastasis appears to shift in parallel with the adhesion of $\mathrm{CHO}$ cells to fibronectin, except for $\alpha 5 \mathrm{CHO}$ cells that do not develop a primary site.

\section{Adhesion of $\alpha 5 \mathrm{~B} 2$ cells to kidney tissue sections and inhibition by GRGDS peptide}

To identify whether kidney metastasis is primarily caused by interactions between $\alpha 5 \beta 1$ on CHO cells and fibronectin in glomeruli, we performed an adhesion assay with frozen sections. In this assay, the artificial binding of $\mathrm{CHO}$ cells to cortex regions such as uriniferous tubules other than glomeruli was seen because of adhesion of tumour cells in the absence of extravasation. Therefore, adhesion of $\alpha 5 \mathrm{~B} 2$ cells to glomeruli was estimated by focusing on the binding of cells (yellow spots) to glomeruli (accumulating red spots) (Figure 5A). The number of cells on glomeruli for the different $\mathrm{CHO}$ cell types investigated is shown in

A
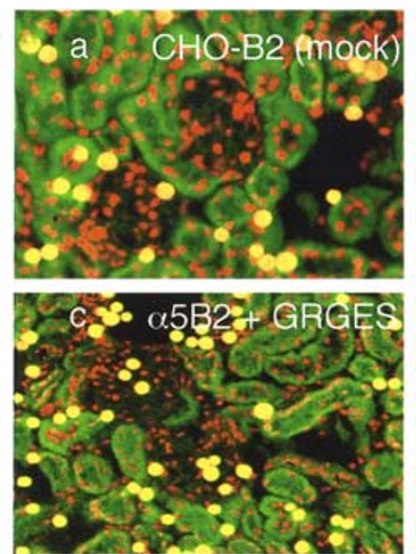

B

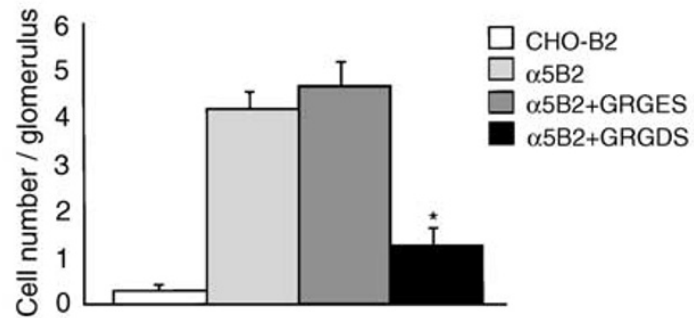

Figure 5 Effects of GRGDS peptide on adhesion of $\alpha 5 B 2$ to the glomerulus in the kidney section. (A) Laser microscopic appearance of adhesion assay on the kidney section. $10^{5}$ cells/section were incubated for 30 min with gentle rotation. a, CHO-B2 cells (yellow spots), $\alpha 5$-defective mutant, slightly adhere to the glomerulus (red spots). b, $\alpha 5 B 2$ cells which were $\alpha 5$ transfectants effectively adhered to the glomerulus. c, Adhesion of a5B2 cells to the glomerulus was not changed by administration of $200 \mu \mathrm{g} \mathrm{ml}^{-1}$ GRGES peptide. d, Adhesion of $\alpha 5 \mathrm{~B} 2$ cells to the glomerulus was inhibited by administration of $200 \mu \mathrm{g} \mathrm{ml}^{-1}$ GRGDS peptide. (B) Cell number per glomerulus $(n=20)$. Note that adhesion of $\alpha 5 B 2$ cells with GRGDS treatment to the glomerulus was significantly inhibited as compared with GRGES treatment $(* P<0.000 I)$. 
Figure 5B. $\alpha 5 \mathrm{~B} 2$ cells adhered well to glomeruli whereas CHO-B2 cells with no $\alpha 5 \beta 1$ hardly adhered at all. The adhesion of $\alpha 5 \mathrm{~B} 2$ cells to glomeruli was significantly inhibited by the administration of GRGDS peptide, but not by GRGES peptide, when compared with the adhesion of $\alpha 5 \mathrm{~B} 2$ cells with no treatment $(P<0.0001)$. These findings demonstrate that micrometastasis in glomeruli in mice may occur through interactions between $\alpha 5 \beta 1$ on tumour cells and fibronectin in the glomeruli.

\section{DISCUSSION}

In this study, we constructed $\mathrm{CHO}$ cell types with various levels of integrin $\alpha 5 \beta 1$ to investigate the relation between $\alpha 5 \beta 1$ expression on tumour cells and organ-preferential metastasis. Furthermore, we focused on alterations of the metastatic rate associated with different levels of $\alpha 5 \beta 1$. Previous studies have reported that the expression of $\alpha 5 \beta 1$ on tumour cells is inversely correlated with tumourigenicity (Giancotti and Ruoslahti, 1990; Schreiner et al, 1991). Moreover, the loss of fibronectin or $\alpha 5 \beta 1$ on tumour cells had no effect on tumourigenesis or metastasis in chimeric mice containing many $\alpha 5$-null cells (Taverna et al, 1998). However, it remains unknown how metastatic rates change in the case of abundant $\alpha 5$ expression on tumour cells. Furthermore, since the expression of $\alpha 5 \beta 1$ on tumour cells has been thought to make the phenotype of tumour cells normal, $\alpha 5 \beta 1$ expression might play a minor role in the tumour metastatic process. Here, we report that the expression of $\alpha 5 \beta 1$ on tumour cells is involved in the development of kidney metastasis. The inhibition of kidney metastasis in vivo and the adhesion of $\alpha 5 \mathrm{~B} 2$ cells to kidney sections ex vivo by administration of GRGDS peptide, both suggest that kidney metastasis might be induced by adhesion of tumour cells via $\alpha 5 \beta 1$ to fibronectin in the kidney glomerulus. Since RGD peptide is also found in laminin, collagen, and vitronectin, in addition to fibronectin, GRGDS peptide does not necessarily specifically inhibit the adhesion of $\alpha 5 \beta 1$ to fibronectin. $\mathrm{CHO}$ cells, however, predominantly express $\alpha 5 \beta 1$, and no ligand molecule other than fibronectin has been found in previous reports. Therefore, GRGDS peptide specifically inhibits the adhesion between $\alpha 5 \beta 1$ on $\mathrm{CHO}$ cells and fibronectin. Since a quarter of the total blood volume effused from the heart flows into the kidney (Churg and Sobin, 1982), many tumour cells seem to interact with capillaries in the glomeruli, suggesting the possibility that kidney metastasis could develop from tumour cells physically trapped by vessels. In this study, however, CHO-B2 cells with no $\alpha 5$ did not induce kidney metastasis in mice. Therefore, micrometastasis in glomeruli appears to be brought about primarily by the adhesive interaction of $\alpha 5 \beta 1$ on tumour cells with fibronectin in glomeruli.

In a spontaneous metastasis test, both $\mathrm{CHO}-\mathrm{B} 2$ (mock) cells with no $\alpha 5 \beta 1$ and $\alpha 5 \mathrm{CHO}$ cells with the highest level of $\alpha 5 \beta 1$ did not give rise to kidney metastasis in nude mice, whereas kidney metastases were seen in about $40 \%$ and $25 \%$ of mice inoculated with $\alpha 5 \mathrm{~B} 2$ and $\mathrm{CHO}-\mathrm{K} 1$ cells, respectively (Table 1). This demonstrates that tumour cells have integrin expression levels appropriate for developing metastatic sites. At a primary site, tumour cells with lower levels of $\alpha 5 \beta 1$ show rapid growth adequate for developing metastatic sites. However, once tumour cells intravasate, cells with higher levels of $\alpha 5 \beta 1$ appear to adhere easily to fibronectin to form metastatic sites.

How do tumour cells interact with fibronectin in kidney glomeruli? Since basement membranes of glomerular vessels contain a small amount of fibronectin compared with collagen and laminin (Yurchenco and Schittny, 1990) as well as general basement membranes, $\mathrm{CHO}$ cells with $\alpha 5 \beta 1$ might have difficulty in adhering directly to fibronectin in basement membranes of glomeruli during metastasis. The glomerular capillary is known to have a characteristic structure in relation to its surrounding basement membranes. In glomeruli, several blood vessels are surrounded by a basement membrane along the lateral side of endothelial cells, whereas a common blood vessel is covered with a basement membrane. Furthermore, at the medial side of the glomerular capillary, endothelial cells and mesangial cells without basement membranes are present (Ramzi et al, 1999). Since mesangial cells surrounded by glomerular blood vessels are known to produce ECM proteins containing abundant fibronectin (Couchman et al, 1994), tumour cells seem to interact easily with fibronectin by invading only the endothelial cells but not the basement membranes. On the other hand, lung, adrenal, and lymph node metastatic rates appear to be independent of $\alpha 5$ expression level on $\mathrm{CHO}$ cells. In these organs, integrins other than $\alpha 5 \beta 1$ or other molecules on tumour cells might be involved in the development of metastatic sites in addition to physical trapping of cells by microvessels.

In conclusion, we demonstrated that $\alpha 5$ expression levels on tumour cells might affect kidney metastasis rates. Therefore, the inhibition of kidney metastasis by targeting cell adhesion might be essential for metastasis therapy.

\section{REFERENCES}

Akiyama SK, Larjava H, Yamada KM (1990) Differences in the biosyntheses and localization of the fibronectin receptor in normal and transformed cultured human cells. Cancer Res 50: $1601-1607$

Albelda SM, Buck CA (1990) Integrins and other cell adhesion molecules. FASEB J 4: $2868-2880$

Chan BM, Matsuura N, Takada Y, Zetter BR, Hemler ME (1991) In vitro and in vivo consequences of VLA-2 expression on rhabdomyosarcoma cells. Science 251: $1600-1602$

Chen FA, Repasky EA, Bankert RB (1991) Human lung tumour-associated antigen identified as an extracellular matrix adhesion molecule. $J$ Exp Med 173: $1111-1116$

Churg J, Sobin LH (1982) Renal Disease: classification and Atlas of Glomerular Diseases, pp 23-32. Igaku-Shoin Ltd.: Tokyo

Couchman RC, Beavan LA, McCarthy KJ (1994) Glomerular matrix synthesis, turnover and role in mesangial expansion. Kidney Int 45: $328-335$

Ewing J (1928) A Treatise on Tumours, 3rd edn. Philadelphia: W.B. Saunders

Giancotti FG, Ruoslahti E (1990) Elevated levels of the $\alpha 5 \beta 1$ fibronectin receptor suppress the transformed phenotype of Chinese hamster ovary cells. Cell 60: 849-859
Hall PA, Coates P, Lemoine NR, Horton MA (1991) Characterization of integrin chains in normal and neoplastic human pancreas. J Pathol 165: $33-41$

Heino J (1993) Integrin-type extracellular matrix receptors in cancer and inflammation. Ann Med 25: $335-342$

Hynes RO (1992) Integrins: versatility, modulation and signaling in cell adhesion. Cell 69: 11-25

Irie A, Kamata T, Puzon-McLaughlin W, Takada Y (1995) Critical amino acid residues for ligand binding are clustered in a predicted beta-turn of the third $N$-terminal repeat in the integrin alpha 4 and alpha 5. EMBO J 14: $5550-5556$

Matsuura N, Puzon-McLaughlin W, Irie A, Morikawa Y, Kakudo K, Takada $Y$ (1996) Induction of experimental bone metastasis in mice by transfection of integrin $\alpha 4 \beta 1$ into tumour cells. Am J Pathol 148: 55-61

Moretti S, Martini L, Berti E, Pinzi C, Giannotti B (1993) Adhesion molecule profile and malignancy of melanocytic lesions. Melanoma Res 4: 235239

Mosesson MW, Umfleet RA (1970) The cold-insoluble globlin of human plasma. I. Purification, primary characterization, and relationship to fibronectin and other cold-insoluble fraction components. J Biol Chem 245: $5728-5736$ 
Natali PG, Nicotra MR, Bartolazzi A, Cavaliere R, Bigotti A (1993) Integrin expression in cutaneous malignant melanoma: association of the $\alpha 3 \beta 1$ heterodimer with tumour progression. Int J Cancer 54: 68-72

Natali PG, Nicotra MR, Botti C, Mottolese M, Bigotti A, Segatto O (1992) Change in expression of $\alpha 6 \beta 4$ integrin heterodimer in primary and metastatic breast cancer. Br J Cancer 66: 218-322

Natali PG, Nicotra MR, Cavaliere R, Giannarelli D, Bigotti A (1991) Tumour progression in human malignant melanoma is associated with changes in

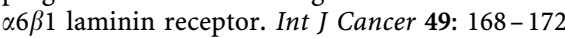

Netland PA, Zetter BR (1984) Organ-specific adhesion of metastatic tumour cells in vitro. Science 224: 1113-1115

Nicolson GL (1988) Organ specificity of tumour metastasis: role of preferential adhesion, invasion and growth of malignant cells at specific secondary sites. Cancer Metastasis Rev 7: $143-188$

Nicolson GL, Winkelhake JL (1975) Organ specificity of blood-borne tumour metastasis determined by cell adhesion? Nature 255: 230-232

Paget S (1898) The distribution of secondary growths in cancer of the breast. Lancet 1: $571-573$

Palecek SP, Loftus JC, Glusberg MH, Lauffenburger DA, Horwitz AF (1997) Integrin-ligand binding properties govern cell migration speed through cell-substratum adhesiveness. Nature 385: 537-540

Palecek SP, Schmidt CE, Lauffenburger DA, Horwitz AF (1996) Integrin dynamics on the tail region of migrating fibroblasts. J Cell Sci 109: $941-952$

Pauli BU, Lee CL (1988) Organ preference of metastasis: the role of organspecifically modulated endothelial cells. Lab Invest 58: 379-387

Pignatelli M, Handy AM, Stamp GW (1991) Low expression of $\beta 1, \alpha 2$ and $\alpha 3$ subunits of VLA integrins in malignant mammary tumours. J Pathol 165: $25-32$

Ramzi SC, Vinay K, Tucker C (1999) Pathologic Basis of Disease, 6th edn, pp 930 -996. PA, USA: W.B. Saunders Company

Regen CM, Horwitz AF (1992) Dynamics of beta 1 integrin-mediated adhesive contacts in motile fibroblasts. J Cell Biol 119: 1347-1359
Ruoslahti E. (1992) Control of cell motility and tumour invasion by extracellular matrix interactions. Br J Cancer 66: 239-242

Schreiner CL, Bauer JS, Danilov YN, Hussein S, Sczekan MM, Juliano RL (1989) Isolation and characterization of Chinese hamster ovary cell variants deficient in the expression of fibronectin receptor. J Cell Biol 109: $3157-3167$

Schreiner CL, Fisher M, Hussein S, Juliano RL (1991) Increased tumourigenicity of fibronectin receptor deficient Chinese hamster ovary cell variants. Cancer Res 51: $1738-1740$

Stamper Jr HB, Woodruff JJ (1976) Lymphocyte homing into oymph nodes: in vitro demonstration of the selective affinity of recirculating lymphocytes for high endothelial venules. J Exp Med 144: 828 - 833

Takebe Y, Seiki M, Fujisawa J-I, Hoy P, Yokota K, Arai K-I, Yoshida M, Arai N (1988) SR $\alpha$ promoter: an efficient and versatile mammalian cDNA expression system composed of the simian virus 40 early promoter and the R-U5 segment of human T-cell leukemia virus type 1 long terminal repeat. Mol Cell Biol 8: 466-472

Taverna D, Ullman-Cullere M, Rayburn H, Bronson RT, Hynes RO (1998) A test of the role of $\alpha 5$ integrin/fibronectin interactions in tumourigenesis. Cancer Res 58: $848-853$

Weaver VM, Petersen OW, Wang F, Larabell CA, Briand P, Damsky C, Bissell MJ (1997) Reversion of the malignant phenotype of human breast cells in three-dimensional culture and in vivo by integrin blocking antibodies. J Cell Biol 137: 231-245

Yurchenco PD, Schittny JC (1990) Molecular architecture of basement membranes. FASEB J 4: 1577-1590

Zhu D, Cheng CF, Pauli BU (1991) Mediation of lung metastasis of murine melanomas by a lung-specific endothelial cell adhesion molecule. Proc Natl Acad Sci USA 88: 9568 -9572

Zutter MM, Krigman HR, Santoro SS (1993) Altered integrin expression in adenocarcinoma of the breast: analysis by in situ hybridization. Am J Pathol 142: 1439-1448 